\title{
THE CONSTRUCTION OF EXCLUSION CLAUSES UPON AFFIRMATION OF A FUNDAMENTAL BREACH
}

\author{
TONY DUGDALE* and N. V. LOWE**
}

Problems are raised by Lord Reid's judgment in Suisse Atlantique in which he proposes that, upon affirmation of a fundamental breach, the applicability of exclusion clauses is a matter of construction. The authors contend that the correct analysis of this proposal requires two stages of construction: first, to determine whether there was, in fact, a fundamental breach, and second, to establish whether the clauses apply to the breach.

It has been generally accepted that after Suisse Atlantique ${ }^{1}$ where a contract has been affirmed following a fundamental breach the application of an exclusion clause is simply a matter of construction. ${ }^{2}$ This proposition seems to have given rise to little concern. ${ }^{3}$ The controversy has always been about the effect of the innocent party choosing not to continue with the contract after an alleged fundamental breach. It is the purpose of this note to show that applying principles of construction to a fundamental breach raises problems which are far from simple.

\section{CONSTRUCTION - TWO STAGES}

At first sight, the position upon affirmation does appear simple. According to Lord Reid in Suisse Atlantique, the true analysis is that the whole contract including the exclusion clause does survive but that the continued existence of the clause does not necessarily avail the party in breach: the applicability of the clause depends upon construction. His Lordship added that: ${ }^{4}$

it cannot be said as a matter of law that the resources of the English language are so limited that it is impossible to devise an exclusion clause which will apply to at least some cases of fundamental breach ....

However, earlier in his judgment Lord Reid had stated that in order to determine whether there has been a fundamental breach, the court should ask whether the situation which has arisen is: ${ }^{5}$

fundamentally different from anything which the parties could, as reasonable men, have contemplated when the contract was made.

Surely in determining what the parties contemplated when the contract was made, the court must first have construed the contract itself and in so doing we would submit that the court must consider the effect of any exclusion

- Lecturer in Law, University of Bristol.

* Lecturer in Law, University of Bristol.

1. [1967] 1 A.C. 361

2. See Fridman (1969) 7 Alta. L.R. 281; Coote 1970 C.L.J. 221; Legh-Jones \& Pickering (1970) 86 L.Q.R. 513 and (1971) 87 L.Q.R. 515; Dawson (1975) L.Q.R. 380. For the position in Scotland see Thomson 1977 Juridical Review 38.

3. Thus The English Unfair Contract Terms Act 1977 for example pays little attention to the problems of affirmation, its only relevant provision being:

"Where on a breach the contract is nevertheless affired by a party entitled to treat it as repudiated, this does not of itself exclude the requirement of reasonablenes in relation to any contract term" $8.9(2)$.

4. Supra n. 1 at 399 C.

5. Id., at $397 \mathrm{G}$. 
clauses ${ }^{6}$ Hence, if a fundamental breach is established the court should have found that despite any exclusion clause, the situation was still outside the parties' contemplation. How then can the court subsequently find that an exclusion clause applies to the fundamental breach? It appears contradictory to say that on the one hand the breach is outside the parties' contemplation and yet on the other hand that they contemplated that the exclusion clause should apply to the breach. We would suggest that the answer to the apparent paradox lies in recognising that there are two stages of construction: the first to determine whether there has been a fundamental breach and the second to determine whether an exclusion clause applies to the established breach.

\section{A. First Stage - Determining Whether There Has Been A Fundamental Breach}

The first stage of construction is for the court to determine whether there has been a fundamental breach at all. At this stage, the court should obviously consider clauses which purport to qualify the contractual obligations undertaken although such clauses may not be the only factors to be taken into account. Indeed, such clauses must always succeed or fail at the first stage of construction. If the clause is found to qualify successfully the obligation so that the alleged breach becomes no breach of the obligation undertaken, then of course no question of fundamental breach or affirmation arises. An example is The Angelia ${ }^{8}$ where the relevant clause stated inter alia that the charterer was not to be liable for failure to supply cargo "due to unavoidable hindrances". Kerr J. held that the correct analysis of the contract was that: ${ }^{\theta}$

the charterers did not undertake an absolute obligation to supply cargo but merely a qualified obligation to do so unless prevented by avoidable hindrances.

6. Our view is contrary to that expressed by Lord Denning M.R. in Farnworth Finance v. At. tryde [1970] 2 All E.R. 774, where he stated at 777

... we must see if there was a fundamental breach of the contract. If there was then the exempting condition should not be construed as applying to it. We look therefore to the terms of the contract, express or implied (apart from the exception clauses)and see which of them were broken. If they were broken in a fundamental respect, the finance company cannot rely on the exception clauses.

Although it might have been possible to justify ignoring the exclusion clause in Farnworth itself as the clause would have had the effect of rendering the contract a mere declaration of intent (see infra $n .12$ and $n$. 13) we submit that the better approach would have been to say that even taking the clause into account, it still did not apply and hence there was a fundamental breach.

7. In Findlay v. Couldwell (1976) 69 D.L.R. (3d) 320 , the court took into account precontractual representations in order to determine the parties' presumed intentions. A court might also consider the reasonable expectations of the parties. Where the parties are of equal bargaining strength it is suggested that the express terms of the contract would be decisive in determining what the parties could reasonably expect. In other situations, however, reasonable expectations might well be regarded as being based more on the nature of the contract rather than on its express terms. On this basis an exclusion clause conflict. ing with the overall nature and intent of the contract could be disregarded in assessing the parties' expectations. This may be what the English legislators had in mind when they provided in s.3)2)(b)(i) of the Unfair Contract Terms Act 1977, that a term of a contract cannot entitle a party to claim

"to render performance substantially different from that which was reasonably ex. pected of him ..., except in so far as ... the contract term satisfies the requirement of reasonableness."

8. [1973] 2 All E.R. 144.

9. Id., at $162 \mathrm{E}$. 
Consequently, it was held that (on the assumption that there were unavoidable hindrances) the charterers' failure to deliver the cargo could not be said to amount to any breach of the contract, fundamental or otherwise. Conversely, if an exclusion clause is too wide then even though it is intended to qualify the obligation it will he held ineffective if it would reduce the contract to a mere declaration of intent. ${ }^{10}$ An example is Farnworth Finance v. Attryde ${ }^{11}$ where, in a contract for the hire purchase of a new motorcycle, it was stated that the vehicle supplied was "subject to no conditions or warranties whatsoever express or implied". In all the circumstances the sensible conclusion was that this was a contract of sale by description and on that assumption the clause could have no effect without reducing the contract to one of intent. ${ }^{11 a}$ We would add, however, that this is not the invariable interpretation of a blanket exclusion clause. ${ }^{12}$ Its inclusion might well be indicative of the parties' intention to contract for the very object before them, whatever it may be. In Farnworth, for example, the parties could conceivably have been contracting not for a new motorcycle but for the very object before them. ${ }^{18}$ In other words the contract may not have been a sale by description.

The court may also at this stage consider clauses which purport to limit liability for an admitted breach. Although at first sight such clauses may seem only relevant to the second stage of construction, when considered with the contract as a whole such clauses may indicate the scope and extent of the obligation undertaken by the parties and hence whether there has been a fundamental breach. An exclusion clause which limits the remedy available upon breach to damages only may itself provide some indication of what was contemplated by the parties. In much the same way as we argued that the blanket exclusion clause in Farnworth could have operated, so a clause limiting the buyer's remedy to damages only and excluding the right to reject could be taken to confine the contract to the very article, whatever it may be, before the two parties. ${ }^{14}$

10. See e.g. Lord Wilberforce in Suisse Atlantique [1967] 1 A.C. 361 at 432 A.

"One may safely say that the parties cannot, in a contract, have contemplated that the clause should have so wide an ambit as in effect to deprive one party's stipulations of all contractual force; to do so would be to reduce the contract to a mere declaration of intent."

See also the comments of Weatherston J. in Cain v. Bird Cheurolet-Oldsmobile Ltd. 69. D.L.R. (3d) 484.

11. [1970]2 All E.R. 774. The clause would now be void in English Law by s.6(2)(a)of the Unfair Contract Terms Act 1977, provided it was a sale by description.

11a. See the comments of Legh-Jones and Pickering (1970) 86 L.Q.R. at 521, 522.

12. It is for this reason that we disagree with the approach of Lord Denning M.R. in Farnworth Finance v. Attryde. See supra n. 6 and infra n. 13.

13. On the approach taken by Lord Denning, M.R. this interpretation would not be possible as the court would never examine the exclusion clauses in order to determine the parties' intention.

14. The distinction between clauses which purport to qualify the contractual obligations undertaken and those which purport to limit liability for an admitted breach has been drawn by Professor Coote, who termed the former clause as 'Type A' and the latter as Type B'. Coote, Exception Clauses (1964) at 9.

We would suggest that the distinction between the two stages of construction is more fun. damental than that between the two types of clauses. In the Angelia [1973] All E.R. 144 at $163 \mathrm{~b}$. Kerr J. stated that the effect of the clause

"cannot depend on the semantic question of whether the Charterparty says: I promise to supply a cargo but shall not be liable if I do not do so due to unavoidable hindrances', or

I promise to supply a cargo unless prevented by unavoidable hindrances'." 


\section{B. Second Stage - Determining Whether the Clause is Intended To Cover The Affirmed Breach}

Once it has been determined that there has been a fundamental breach, then the court must proceed to the second stage of construction, namely, determining whether the exclusion clause in the contract nevertheless provides a defence to the breach. At this stage only clauses which seek to limit or exclude liability for a breach are directly relevant. These clauses should be construed with the rest of the contract to see whether they were intended to apply to the particular breach remembering that, as Lord Reid said, ${ }^{15}$ despite affirmation, there is still a presumption that a clause is not intended to apply to a breach going to the root of the contract. In other words, it is not sufficient to look at the clause in isolation from the rest of the contract and determine whether as a matter of construction the particular clause covered the particular breach.

It must be absolutely clear that the clause seeking to limit or exclude liability for the breach is to apply in all possible circumstances including that of an affirmed fundamental breach. Although it may be difficult to show this intention, it is (as Lord Reid said) not impossible to devise such a clause. ${ }^{16}$ Thus we would venture to suggest that it is more reasonable to suppose that a limitation of damage clause was intended to apply to an affirmed fundamental breach than it would be in the case of a clause seeking to exclude liability altogether. Similarly, where there is an agreed damage clause as in Suisse Atlantique itself, it is even more reasonable to suppose that it was intended to apply to an affirmed fundamental breach as it could favour either party.

C. Significance Of The Two Stage Analysis

Clearly then the two stages are closely interrelated because at the second stage of construction, the court will be influenced by the conclusion it has reached at the first stage. But it is important to separate the stages, for otherwise as the cases illustrate, there is a danger that one or other of the construction issues will be neglected by the court. It may decide that there has been a fundamental breach without construing the exclusion clauses at all and then concentrate only on the question whether the exclusion clauses can apply as a defence to the fundamental breach. Conversely it may construe the exclusion clauses solely in the context of -whether they render the 'breach situation' no breach at all and having once decided that the clauses are inapplicable in that sense, ignore the question whether the clauses can apply as a defence to the breach.

Furthermore if construction is simply seen as one overall process, there is an added danger that the court will conclude that the result of the process will not change whether the contract is terminated or affirmed. Indeed, this is true of the first construction issue - determining whether there has been a

Similarly we have argued that Type B clauses as well as Type A clauses may be relevant at the first stage of construction. Thus the crucial question is not the 'semantic' appearance of the clause nor even its purported effect, but rather the issue of construction which the court is considering.

For a slightly different analysis of types of exclusion clauses see Donaldson J. in Kenyon, Son \& Craven Ltd. v. Baxter Hoare \& Co. [1971] 2 All E.R. 708.

15. [1967] 1 A.c. 361 at $398 \mathrm{G}$.

16. Id., at $399 \mathrm{C}$. 
breach by the guilty party - for a clause which purports to qualify the obligation of a party and fails to do so will not avail the party upon affirmation. To this extent we agree with Lord Denning, M.R. in Farnworth v.Attryde that, even if there had been an affirmation of the breach, the "no conditions and warranties" clause would not have protected the plaintiffs from liability for their breach. ${ }^{17}$ In the case of a clause purporting to limit liability for breach, however, affirmation may make a difference to the result of the construction, for it is arguable that such a clause should normally be construed as applying only when the contract has been affirmed. In this situation the clause would be operating in the context of a continuing relationship in which the innocent party could still be receiving benefits from the the guilty party's performance. In contrast, if the contract has been terminated, the innocent party is no longer expecting further performance or benefits from the guilty party, a final settlement of the parties' relationship has to be made and, in this context, operation of a limitation of liability clause may be far more prejudicial to the interest of the innocent party than it would be in the context of an affirmed contract. Thus, applying the contra proferentum rule, the clause should be construed as not applying if the contract has been terminated unless the wording of the clause or of the contract as a whole clearly indicated that it should apply in such a situation. It is important to note that affirmation has not altered. the construction of the clause, but rather that the construction of the clause depends on whether the contract has been affirmed or terminated after the fundamental breach. Affirmation thus alters the effect, not the construction, of the clause.

The significance of the two stage analysis and the dangers of neglecting it are well illustrated by examining the approaches of the Ontario Court of Appeal in R.G. McLean v. Canadian Vickers Ltd. ${ }^{18}$ the English Court of Appeal in Wathes v. Austin ${ }^{10}$ and the Alberta Supreme Court in Inelco Industries $L t d$. V. Venture Well Services Ltd. ${ }^{20}$ In all three cases the courts failed to distinguish the two stages of construction and in our submission, may thereby have reached unsatisfactory conclusions.

D. R.G. McLean v. Canadian Vickers Ltd.

In McLean's case the defendant supplied a printing press to the plaintiffs under a contract which provided inter alia that the defendants would repair or replace the machine if it was defective due to faulty workmanship or materials, but that otherwise the defendant excluded liability for:

All express conditions, warranties, or liabilities of any kind relating to the goods sold whether as to fitness or otherwise and whether arising under the Sale of Goods Act 1893 or other Statute or in tort or by implication of Law or otherwise. In no event shall we be liable for any direct or indirect loss or damage (whether special, consequential, or otherwise) or any other claims except as provided for in these conditions.

The press was defective and failed to produce the high quality printing contemplated by both parties. After unsuccessfully attempting to repair the press, the defendant offered to take it back and to return the instalments of

17. [1970] 2 All E.R. 774 at 778 F.

18. (1971) 15 D.L.R. (3d) 15.

19. [1976] 1 Ll. Rep. 14. For a discussion of the decision see Reynold (1976) 92 L.Q.R. 172; Coote (1977) 40 M.L.R. 31; Adams (1978) 41 M.L.R. 92; Thomson 1977 Juridicial Review 46 and 47.

20. (1975) 59 D.L.R. (3d) 458. 
the purchase price already paid. The plaintiffs, however, did not accept the offer but continued to operate the press at a loss, insisting that the defendant should make further efforts to repair the press. When the defendant claimed for the remaining unpaid instalments of the purchase price, the plaintiff counterclaimed for their losses incurred both before and after the date of the defendant's offer.

Applying our analysis, the court should first have considered the contract as a whole including the exclusion clause to determine whether the parties contemplated that such defective performance should have been regarded as being within the terms of the contract. Having concluded that despite the 'no condition or warranties' section of the clause the performance was outside the parties' contemplation and therefore a fundamental breach, it should then have considered whether the limitation of liability' section of the exclusion clause should have been construed as being applicable to the fundamental breach. In fact it was held that the defendant had been guilty of a fundamental breach for the ${ }^{21}$

machine simply did not do the job which it had been purchased to do and could not be made to do it all by all the efforts of both parties.

The court then held the exclusion clause as a whole inapplicable, as to hold otherwise "would make the ostensible obligations of the parties ... a mere declaration of intention". ${ }^{22}$ With respect, while the 'no conditions or warranties' section of the clause would have appeared to render the supplier's obligation nugatory, ${ }^{23}$ this was not necessarily true of the limitation of liability section of the clause for that would have left the supplier still liable to replace or repair. In our submission the court was at fault in dismissing the clause as a whole without directing specific attention at that last part of the clause. This mistake would have been avoided if the court had adopted our approach. ${ }^{24}$

E. Wathes v. Austin

Wathes had contracted to supply and install an air conditioning plant in Austin's store. Clause 14 of the contract stated:

consequential damages. The company shall be under no liability for any consequential loss, damage, claims or liabilities of any kind from any cause whatsoever.

When installed, the extractor fan of the plant proved to be so noisy that it seriously interfered with the business of a neighbouring store, whose proprietors threatened and subsequently commenced legal proceedings against Austin for nuisance. Austin, who had decided to keep the plant despite the noise problem, eventually settled the legal action on the basis that they would arrange for the installation of a screen to abate the noise. When Wathes claimed the contract price of $£ 1,338.50$, Austin counterclaimed for the sum of $£ 1,323$, being the cost of the installation of the screen and the settlement of the legal action. Wathes claimed that these expenses were irrecoverable under the terms of Clause 14 . Austin responded by arguing that Clause 14 could not be construed as applicable since the expenses resulted

21. Supra n. 18.

22. Id., at 20.

23. The 'no conditions or warranties' part of the clause would appear to render nugatory even the express obligation to 'repair or replace'.

24. For another example of the overall construction approach see Cain v. Bird Cheurolet. Oldsmobile Ltd. (1976) 69 D.L.R. (3) 484 at 486. 
from a fundamental breach. Wathes' first counter-argument was that they were not guilty of a fundamental breach. This argument was rejected by the Court of Appeal on the basis that the supply of the air conditioning plant, which caused excessive noise when operated, was "something totally different from that which the contract contemplated and was a fundamental breach". ${ }^{25}$

Wathes' second counter-argument, as interpreted by the Court, was that even accepting that there had been a fundamental breach, Austins were bound by the exclusion clause, since by affirming the contract they must have been taken to have affirmed the application of the exlusion clause and consequently to have waived their right to rely on the fundamental breach in order to defeat the exclusion clause. As Wathes' counsel had, according to Megaw, L.J., conceded that the exclusion clause would have been inapplicable if the contract had been terminated, ${ }^{25}$ a counsel was taken to be suggesting that the effect of the exclusion clause altered upon affirmation. The Court of Appeal rejected this argument. Megaw, L.J. stated that::28

Since Clause 14 would not, as a matter of construction, have availed the plaintiffs if the contract had been treated as rescinded for a fundamental breach, on Lord Reid's reasoning, it would not avail the plaintiffs when there is a fundamental breach, but no rescission.

The reasoning of Lord Reid referred to by Megaw, L.J. was as follows. ${ }^{27}$

... then the true analysis seems to me to be that the whole contract, including the clause excluding liability, does survive after election to affirm it, but that that does not avail the party in breach. The exclusion clause does not change its meaning: as a matter of construction, it never did apply and does not, after election, apply to this type of breach.

At first glance, this statement seems to justify the conclusion drawn by Megaw, L.J. but if the two-stage analysis of construction is applied then the conclusion must be questioned. The exclusion clause in Wathes case purported to limit liability for breach and was, therefore, relevant to the second stage of construction. As we have argued, affirmation may change the effect of such a clause; it would normally not be construed as applying if the contract had been terminated, but might well be construed as applying if the contract had been affirmed. In other words, it is not sufficient to say that because the clause would not have applied had the contract been terminated it must necessarily not apply upon affirmation. On this analysis, it was essential to ascertain why counsel conceded that the exclusion clause would not have applied if the contract had been terminated. If the concession was on the basis that the clause was only intended to apply when the contract was

25. Supra n. 19 at $21 \mathrm{Col} 1$.

25a. The concession was probably made in view of the reasoning of Lord Denning M.R. in Har. butt' Plasticine'v. Wayne Tank \& Pump Co. [1970] 1 Q.B. 447. There Lord Denning, M.R. held that if a contract was terminated as a result of a fundamental breach then as a matter of law all exclusion clauses in the contract ceased to have any effect.

Interestingly 8.9(1) of the Unfair Contract Terms Act 1977 provides that

"Where for reliance upon it a contract terms has to satisfy the requirement of reasonableness, it may be found to do so and be given effect accordingly notwithstanding that the contract has been terminated either by breach or by a party electing to treat it as repudiated."

The provision is designed to reverse the rule in Harbutt's Plasticine' and hence a concession such as that made by counsel in Wathes would no longer be necessary - if it was ever necessary in the first place.

26. Supra n. 19 at 22 Col 1.

27. [1967] 1 A.C. 361 at 399 A. 
"on foot", then counsel should not have been precluded from arguing that the clause applied upon affirmation. It may well be that, wide though the clause was, it could still not be construed as being applicable to the particular damage, ${ }^{28}$ but in missing this second stage of construction Megaw, L.J.seems to preclude the possibility of any clause being so applicable.

The error in Megaw, L.J.'s analysis is that he fails to distinguish the reason for the clause being inoperative on termination from the reason for it being inapplicable on affirmation. Perhaps he was misled by the approach of the Court of Appeal in Charterhouse v. Tolley ${ }^{20}$ on which he relied. In Charterhouse, the Court was applying a rule that upon a fundamental breach exclusion clauses must as a matter of law rather than construction be inaaplicable whether or not there has been affirmation. On this reasoning, the inapplicability of the clause was indeed the same whether or not the contract was affirmed. Charterhouse must be doubtful authority following the criticism of the "rule of law" approach made by the House of Lords in Suisse Atlantique. ${ }^{30}$ But even if Charterhouse is reconcilable with Suisse Atlantique on the grounds that the clause was inapplicable as a matter of construction, ${ }^{31}$ it was still inappropriate for the court to rely upon it in Wathes since the clause in Charterhouse - a no conditions or warranties clause - was relevant to the first stage of construction whereas the clause in Wathes was relevant to the second stage. As we have noted, the result of the first stage of construction will remain the same whether the contract is affirmed or terminated and, hence, once it has been decided in a Charterhouse situation that the clause is inapplicable on its construction, it will remain inapplicable even if the contract is affirmed.

The weakness, then, in the decision of Wathes v.Austin lay in the failure to distinguish between the two stages of construction. If such a distinction had been made, the outcome of the case might well have been different. The same criticism may be levelled at the decision of the Alberta Supreme Court in Inelco Industries Ltd. v. Venture Well Services Ltd. ${ }^{32}$

\section{F. Inelco Industries}

The case concerned the leasing of a gas compressor by Inelco to Venture. The lease provided by Clause 9 that the lessee "should bear the entire risk of damage to the equipment from any and every cause whatsoever", by Clause 11 that the lessee "is required to keep the equipment insured against all risks of loss and damage" and by Clause 14 to idemnify Inelco against any and all causes of liability. From the start the compressor was so defective that the court was prepared to assume that "its performance fell so far short of that required by the contract as to go to its very root". ${ }^{33}$ Venture did not reject the compressor but kept it on the basis that Inelco "was prepared to continue

28. Stephenson, L.J. Supra, n. 19 at 24 Col. 1, seemed to take this view, stating that a clause excluding or limiting the liability of the guilty party

"does not cover fundamental breaches unles expressed to do so in the plainest terms."

29. [1963] 2 Q.B. 683.

30. [1967] 1 A.C. 361 at 392 E and 395 B per Viscount Dilhorne, 406 A-B; per Lord Reid, 425 F and $428 \mathrm{~F}$ per Lord Upjohn.

31. Id., $428 \mathrm{G}$ per Lord Upjohn, $433 \mathrm{D}-\mathrm{F}$ per Lord Wilberforce.

32. (1975) 59 D.L.R. (3d) 458.

33. Id., at 466 . 
working on the compressor so as to resolve the problems". ${ }^{34}$ Unfortunately, before Inelco had completed the repairs the compressor was seriously damaged by fire. Even then, Venture did not immediately reject the compressor, but instructed a third party to repair the fire damage and only after those repairs had been completed did Venture ask Inelco to remove the compressors which they did.

The third party sued Venture for the cost of repairs and in turn Venture claimed an indemnity from Inelco, arguing that, as Inelco had committed a fudamental breach by delivering a totally defective machine, all the contractual terms ceased to apply and hence Venture were not liable for the damage under Clauses 9, 11 and 14. The Court held that Venture's actions amounted to affirmation and that consequently they could not argue that the provisions of the contract were inapplicable. On the contrary, the three clauses were construed as protecting Inelco for as the Court commented, to hold otherwise. ${ }^{.5}$

would be to sweep aside an important element involved in most leasing arrangements. This is particularly so where, as here, a lessee in possession of equipment that he knows to be defective has not advised the lessor that he no longer considers himself responsible for the loss of damage that may occur.

The emphasis given to the fact that the lessee had affirmed the contract rather than 'advising' the lessor that he would not be responsible for the loss or damage (which presumably would not have been considered by Sinclair, J.A. as amounting to affirmation $)^{36}$ suggests that the affirmation itself was regarded as the all-important reason for construing the clauses as protecting Inelco. This seems very like saying that because the contract initially provided that the whole risk of damage was on Venture then necessarily the risk remained on Venture when the contract was affirmed. This process of reasoning would explain why the Court thought it unnecessary to determine whether the fire damage was attributable to Inelco's fundamental breach ${ }^{37}$ although there was some evidence to suggest that it might have been so attributable..$^{38}$

This reasoning produces the opposite result from that produced by the Court of Appeal in Wathes and, in our submission, is equally wrong. Once it had been accepted that the performance of the compressor was so bad as to go to the very root of the contract, there arose a presumption that the exclusion clauses were not intended to apply to damage arising from that breach. Hence, the Court should have expressly directed its attention to the question of whether the three clauses were intended to apply even to damages arising

34. Id., at 461 .

35. Id., at 468 .

36. In Van Dorne v. North American Van Lines (1977) 79 D.L.R. (3d) 42 the Court held that where there has been a repudiatory breach then if an innocent party fails to communicate his intention to the guilty party to treat the contract as discharged, the contract remains in effect.

37. Supra n. at 469.

"In the view I take of this appeal it matters not whether the fire was caused by negligence of Inelco in designing or fabricating the pulse bottle,"

38. Id. at 461 the Court had indicated that one of the consequences of the machine being defective was that "the discharge temperature was (also) too high" and that at the date of the fire "no solution had been found to this problem". 
from a fundamental breach. Only if it was clear that the clauses were intended to apply to a fundamental breach would the question of the cause of the fire be irrelevant, otherwise it was of critical importance. It may well be that the actual decision was correct since the three clauses, particularly the insurance clause, were so widely and clearly drafted as to indicate the intention to put the risk on Venture in spite of the fundamental breach. Nevertheless, it seems clear from the judgment that the Court never entertained a doubt as to the application of the clauses. In other words, the fact that there had been a fundamental breach made no difference in that case.

Interestingly, Sinclair, J.A. added that the court was not concerned with the delivery of something of a kind completely different from that contemplated by the agreement in that it was a compressor that was leased and it was a compressor, albeit a defective one, that was delivered. To illustrate this point, the following example was given: ${ }^{39}$

[L]et us assume that I had rented a horse, agreeing that I would be responsible for the risk of loss or damage to the animal, and that might be caused by it while it was in my care. Suppose that instead of receiving a horse, as I had expected, the lessor sent me a dangerous water buffalo. Not only would that be a fundamental breach of the lease but I would have on my hands the probability of grave risk of a kind totally different than had been contemplated. The very substratum of the lease provisions concerning risk, indemnity and insurance would be gone. Such provisions could hardly be said to apply to all.

With respect to Sinclair, J.A. the above distinction is not so clear, for while the delivery of a water buffalo will obviously carry entirely different risks to the horse, it may also be strongly argued that a defective compressor, the performance of which is so bad as to go to the root of the contract, carries entirely different risks to the workable compressor contemplated by the parties. Perhaps the explanation is that in the water buffalo example, affirmation really amounts to the making of a new contract and the exclusion clause is not to be implied in that new contract, ${ }^{10}$ whereas in the defective compressor example there is no new contract and the application of the exclusion clause depends upon its construction.

\section{CONCLUSION}

The concern of this note has been to demonstrate that more thought needs to be given to the proposition that the application of an exclusion clause to an affirmed fundamental breach depends upon its construction. ${ }^{11}$ The need for

39. Id., at 468.

40. In Suisse Atlantique [1967] 1 A.C. 361 at 404 B, Lord Reid himself seems to have contemplated the possibility of an affirmation amounting to a rescission followed by the mak. ing of a new contract when he commented on the following example raised in Charterhouse by Upjohn L.J. at [1963] 2 Q.B. 710.

"Suppose the finance company contracts to hire a tractor and in purported performance of that contract delivers not a tractor but three fine Suffolk punches which take the fancy of the farmer and for which he can find a use. Can it be said that by affirming the contract and accepting these horses in lieu of the tractor, that the company can escape under some clause of exclusion, so that the farmer can make no claim for dmages for the loss which he suffers by taking the horses in lieu of a tractor."

Upjohn L.J. commented that the farmer was "entitled to have the horses" and "can still say that the company has wholly failed to carry out its part of the bargain by failing to lend what it had contracted to lend."

Lord Reid commented that he would be inclined to think that

"that was not delivery under the contract at all, but that it was an offer of new contract on terms to be implied."

See also Legh-Jones \& Pickering (1971) 87 L.Q.R. 515, 524, 525. 
care is illustrated by the cases we have examined. In McLean it was assumed that because the 'no conditions or warranties' section of the exclusion clause was inapplicable then so also was the limitation of liability' section. In Wathes it was assumed that as the exclusion clauses would not have applied had there been termination, they could not apply upon affirmation. In Inelco it was assumed that because of the affirmation, the fundamental breach could be of no significance. The mistake in all the cases was the failure to consider the function of the exclusion clause and to construe it in the context of the affirmed fundamental breach. ${ }^{42}$

It is our contention that the correct approach should be to first classify the nature and purpose of the exclusion clause itself. If the clause purports to qualify the contractual obligation then it will be relevant to the first stage of construction, namely, determining whether there has been a fundamental breach in the first place. At this first, and often overlooked, stage the court should construe the whole contract including any relevant exclusion clause but recognising that not all such clauses purport to qualify the obligation and that even if they do, they may not be effective if they would destroy the very core of the contract.

If despite the fundamental breach the contract has been affirmed, a second stage of construction arises, namely, to determine whether the breach is covered by the exclusion clause. At this stage the only relevant clauses are those which purport to limit or exempt liability for breach as, for example, a limitation of damage clause or one which states that there is to be no liability for any consequential damages. Even at this stage, however, as Lord Reid pointed out in Suisse Atlantique ${ }^{43}$ there is a presumption that a clause is not intended to apply to a breach going to the root of the contract. Hence to determine the application of the clause to the breach the court should construe the clause with the rest of the contract. Because of the presumption we would suggest that the exclusion clause will only be held applicable if it can be shown that it is intended to apply in all possible circumstances including that of an affirmed fundamental breach. As Lord Reid said: "it cannot be said that the resources of the English language are so limited that it is impossible to devise an exclusion clause which will apply to at least some cases of fundamental breach." ${ }^{\prime 4}$

41. The purpose of this note has been to deal with the problems of construction which arises upon affirmation of a fundamental breach. There are, however, othr problems which arise in the context of an affirmed fundamental breach. See, for example, the question which arose in Canso Chemicals Ltd. v. Canadian Westinghouse Co. Ltd. (1974)54 D.L.R. (3d) 517 as to whether the innocent party's right to damages is lost as a result of his affirmation and the question which arose both in R.G. McLean Canadian Vickers Ltd. and in Beldessi v. Island Equipment (1973) 41 D.L.R. (3d) 147, as to whether the innocent party's damages should be reduced on the ground that affirmation of a fundamental breach amounted to failure to mitigate loss. The question also arose in Wathes v. Austin Id. but was not pursued in the Court of Appeal.

42. It may be commented that the English Unfair Contract Terms Act 1977 far from solving the difficulties of construction in the context of an affirmed fundamental breach, seems in 89 (2) only to add a further element to the problems by introducing a requirement of ressonableness. Commentators suggest that an exclusion clause will first have to be construed and then if applicable on its construction, subjected to the further test of reasonableness. See Rogers \& Clarke "The Unfair Contract Terms Act 1977" (1978), particularly the notes to $8.9(2)$.

43. [1967] 1 A.C. 361 at 399 A.

44. Id., at $399 \mathrm{C}$. 